\title{
LOCAL PARAMETERS OF THE SURFACE ROUGHNESS OF ELECTROCHEMICALLY DEALLOYED Ag-Pd ALLOYS
}

\author{
(C) 2018 E. V. Bedova, M. V. Grechkina, O. A. Kozaderov \\ Voronezh State University, 1, Universitetskaya pl., 394018 Voronezh, Russia \\ e-mail: ok@chem.vsu.ru
}

Received 28.10.2018

\begin{abstract}
Local characteristics of surface roughness of the polycrystalline Ag-Pd solid solutions (4 and 8 at. \% Pd) which underwent potentiostatic electrochemical dealloying in an acidic nitrate aqueous solution were determined by scanning electron and atomic force microscopy. A qualitative analysis of the SEM and AFM micrographs demonstrated substantial morphological roughening of the surface of Ag-Pd alloys. This results from the formation of hollows and cracks caused by selective leaching of electronegative silver and recrystallization of electropositive palladium into its highly-developed phase. A quantitative analysis of the AFM-data allowed us to determine the numerical values of the main local roughness characteristics of anodically modified alloys. The negative value of the coefficient of surface asymmetry indicates the formation of deep cavities during the dealloying process. The recorded mean roughness generally depends on the AFM-scanning zone, but it stabilizes if the scan zone exceeds several tens of micrometers. The roughness of dealloyed Ag-Pd systems is of micro- and nano-size and increases with anodic potential and electric charge of the electrochemical modification of both studied Ag4Pd and Ag8Pd alloys. This effect can be accounted for by a significant rise in the anodic dissolution rate of silver from the alloys in the overcritical region of polarization, resulting in the formation of deeper surface defects. An increase in the average height of surface irregularities with modification time conforms to the square root law, confirming the non-stationary mass transfer kinetics of the selective dissolution process. Variation of the anodic potential and electric charge makes it possible to find the optimal conditions for the electrochemical synthesis of electrode Ag-Pd materials with given values of arithmetic mean and root-mean-square roughness. The assumption that harmonic sinusoidal function represents the Ag-Pd surface microprofile proved the linear dependence of the roughness factor on dealloying time.
\end{abstract}

Keywords: dealloying, Ag-Pd alloys, surface roughening, SEM, AFM.

DOI: https://doi.org/10.17308/kcmf.2018.20/627

\section{INTRODUCTION}

Anodic dissolution and corrosion of alloys often becomes selective [1-3] due to significant difference of components in thermodynamic and electrochemical properties. Selective dissolution (SD) leads to the formation of a non-equilibrium surface layer, whose chemical, phase and microstructural state is changed compared with the bulk of the alloy [4]. Especially significant changes can be appeared if $A-B$ alloy undergoes anodic dissolution in the overcritical region of potentials and charges, when, along with ionization of electronegative component $A$, recrystallization of noble metal $B$ into its own nanoporous or dispersed phase takes place [5-11]. As a consequence, the dealloying process can be used to synthesize electrode materials characterized by a morphologically highly developed surface. Indeed, the corrosive etching of the active metal in a chemically aggressive solution makes it possible to obtain fine powders and monolithic spongy metals, for example, gold $[5,7,10]$, silver [7], and palladium $[6,7,11]$.

The disadvantage of free corrosion dealloying is the uncontrolled pore size of the synthesized material. On the contrary, using electrochemical anodic SD it is possible to regulate the morphological properties and chemical composition of the surface layer of a dealloyed material [8-10], and to obtain nanoporous materials with a highly developed surface structure. Moreover, deep electrochemical etching allows to synthesize materials that do not require additional stabilization in a matrix $[10,11]$. 
The highly developed surface layer forming at SD of an alloy is characterized by an increased area of the electrode / electrolyte interface. The problem of determining the local and integral morphological parameters of the surface of anodically modified alloys is actual both in the kinetic description of the electrochemical processes occurring on it, and in substantiating the possibility of practical use of materials synthesized by the method of selective dissolution.

There are two measures of the surface area of a real solid electrode [12], namely the true surface area $\left(S_{\text {real }}\right)$ and geometric one $\left(S_{\text {geom }}\right)$; their ratio is equal to the roughness factor $f_{\mathrm{r}}[13]$ :

$$
f_{\mathrm{r}}=S_{\text {real }} / S_{\text {geom }} \text {. }
$$

Unfortunately, there is no universal method for determining $S_{\text {real }}$ and $f_{\mathrm{r}}$, because their values depend on the measurement method, on the theoretical model on which this method is based, and on the conditions of its application [14]. In addition, $S_{\text {real }}$ and $f_{\mathrm{r}}$ are the integral parameters of the electrode surface and do not allow describing the local geometric characteristics of the surface. To determine the latter, scanning electron microscopy (SEM) and atomic force microscopy (AFM) methods are used. The arithmetic average roughness $R_{\mathrm{a}}$, the mean square roughness $R_{\mathrm{q}}$ and the radial wavelength $L_{\mathrm{a}}$ make it possible to sufficiently characterize the microrelief of the surface of an alloy subjected to $\mathrm{SD}$. The parameter $R_{\mathrm{a}}$ is defined as the average deviation of all points of the AFM image from the mid-plane, and $R_{\mathrm{q}}$ - as the average value of the measured deviations from the mid-plane. The quantity $L_{\mathrm{a}}$ serves as a parameter of the periodicity of the surface structure and, in fact, is the average distance between adjacent irregularities [15].

The purpose of this work is the microscopic determination of the local characteristics of a highly developed surface of Ag-Pd alloys formed by anodic selective dissolution in an acidic nitrate aqueous solution in the overcritical region of anodic potentials and electric charges.

\section{EXPERIMENTAL}

Polycrystalline homogeneous alloys of the Ag-Pd system with bulk atomic fraction of palladium 4 and 8 at. \% obtained by direct alloying of the components according to the procedure described in [16], were selected for the study. Making electrodes, the alloys were cut, polished, and placed in a frame of polymerized epoxy resin. Preparation of the working surface of the electrodes included stripping on sanding paper, polishing on chamois with an aqueous $\mathrm{MgO}$ suspen- sion to a mirror finish, degreasing with ethyl alcohol, and washing twice with bidistilled water.

Anodic selective dissolution of Ag-Pd alloys was carried out at room temperature in an unmixed and deaerated with argon solution of $0.1 \mathrm{M} \mathrm{KNO}_{3}+0.001 \mathrm{M}$ $\mathrm{HNO}_{3}+0.001 \mathrm{M} \mathrm{AgNO}_{3}$ under potentiostatic polarization conditions using the IPC-Pro-L electrochemical complex in a standard three-electrode cell with non-separated cathode and anode spaces. The auxiliary electrode was Pt. The silver chloride reference electrode was located in a separate vessel and connected to the cell by an electrolytic bridge filled with a saturated solution of ammonium nitrate, with a Luggin capillary. The solution was prepared on bidistilled water using salts of reagent and analytical grade, as well as a pre-standardized solution of acid. The potentials $E$ are given relative to the standard hydrogen electrode scale, the specific charge $q$ is calculated per unit of the true initial surface area of the Ag-Pd electrode, the roughness factor of which is determined by a combined electrochemical method [17].

The critical potentials and charges corresponding to the start of the surface development of the systems under study, evaluated by the chronoamperometry method according to [18], are listed in the table.

Table. The critical potential $E_{\mathrm{cr}}$ and critical charge $q_{\mathrm{cr}}$ of selective dissolution of Ag-Pd alloys in $0.1 \mathrm{M} \mathrm{KNO}_{3}+0.001 \mathrm{M} \mathrm{HNO}_{3}+0.001 \mathrm{M} \mathrm{AgNO}_{3}$

\begin{tabular}{|c|c|c|}
\hline Alloy & $E_{\mathrm{cr}}, \mathrm{mV}$ & $q_{\mathrm{cr}}, \mathrm{mC} / \mathrm{cm}^{2}$ \\
\hline Ag4Pd & 703 & 0.5 \\
\hline Ag8Pd & 717 & 0.8 \\
\hline
\end{tabular}

The morphological development of the surface layer of the Ag4Pd alloy was carried out at a constant overcritical potential $E_{\bmod }>E_{\text {cr }}$ The Ag8Pd alloy was subjected to anodic modification with variable values of both electric charge $q_{\text {mod }}>q_{\mathrm{cr}}$ and electrode potential $E_{\text {mod }}>E_{\text {cr. }}$

Local data on the surface microrelief of Ag$\mathrm{Pd}$ electrodes were obtained on JSM-6510LV electron microscope (JEOL Ltd) and on Solver P47PRO atomic force microscope (NSG 20 cantilever, made of silicon and coated with gold) in a semicontact (intermittent-contact) scanning mode of a sample. The surface study of the samples was carried out at five different points of a scanning area of mesoscopic $\left(65 \times 65 \mu \mathrm{m}^{2}, 10 \times 10 \mu \mathrm{m}^{2}\right)$ and microscopic $\left(2 \times 2 \mu \mathrm{m}^{2}, 1 \times 1 \mu \mathrm{m}^{2}\right)$ size. The local parameters of the surface microrelief were found from the data of digital and statistical processing of the obtained AFM images in the Gwyddion 
2.30 soft. The results of the SEM and AFM studies were obtained in the Voronezh State University Center for collective use of scientific equipment (CKPNO VGU).

\section{RESULTS AND DISCUSSION}

Micrographs of the surface of the samples obtained by the SEM method confirm the substantial morphological development of the surface layer of Ag-Pd alloys after their overcritical selective dissolution (Fig. 1). Figures 2 and 3 show the AFM images and surface microprofiles of the studied Ag-Pd alloys. Along with the texture caused by the preparation of the samples for the experiment, there are additional cavities formed directly during the process of electrochemical dissolution of silver from the Ag-Pd alloy.

The advantage of the AFM method in comparison with scanning electron microscopy is the ability to determine the numerical values of the local roughness characteristics of anodically modified alloys. For instance, the analysis

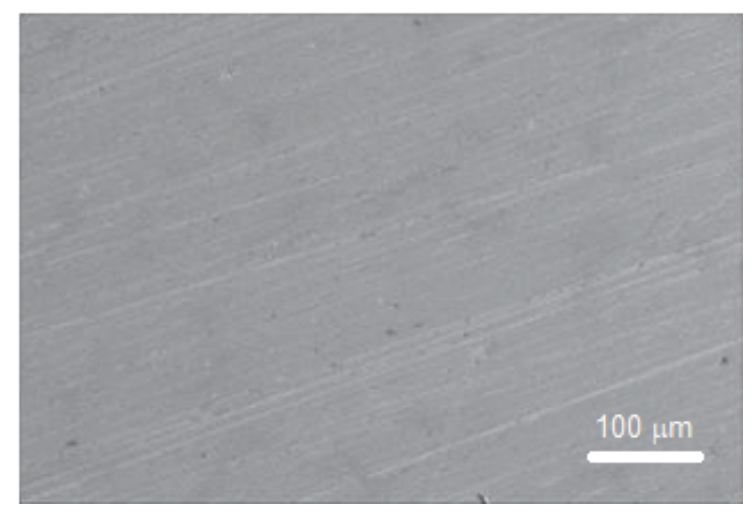

$a$

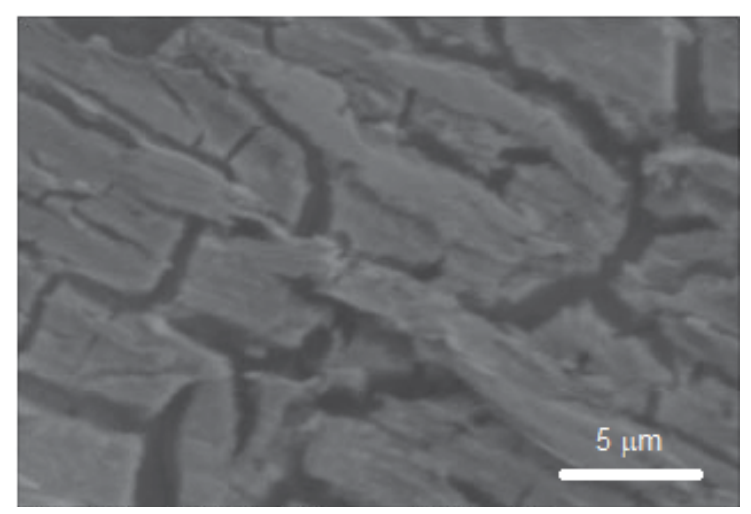

$b$

Fig. 1. SEM images of the surface of $\operatorname{Ag} 4 \mathrm{Pd}(a, b)$ and $\operatorname{Ag} 8 \mathrm{Pd}$ alloys $(c, d)$ in the initial state $(a, c)$ and after anodic modification $(b, d)$. Modification mode: solution $0.1 \mathrm{M} \mathrm{KNO}_{3}+0.001 \mathrm{M} \mathrm{HNO}_{3}+0.001 \mathrm{M} \mathrm{AgNO}_{3}$, modification potential $E_{\text {mod }}=E_{\text {cr }}+185 \mathrm{mV}$, charge $q_{\text {mod }} \cong 500 q_{\text {cr }}$ showed that the coefficient of asymmetry, which characterizes the skewness of the distribution of the microprofile [15], takes mostly negative values. This indicates that not protrusions predominate on the surface of the anodically modified alloy, but hollows formed, apparently, during the selective dissolution of silver and recrystallization of palladium.

It turned out that the microscopically detected root-mean-square roughness $R$ increases with the size of the scanning zone $\left(L_{x y}\right)$ if $R_{\mathrm{q}}>L_{\mathrm{xy}}$. However, under the condition $L_{\mathrm{xy}}>50 \mu \mathrm{m}$, this parameter reaches an almost constant value (Fig. 4). This is consistent with the literature data on the ambiguity of the results of determining morphological characteristics by microscopic methods, if the characteristic length of the scan area does not exceed the average size of the irregularities of the surface under study $[15,19,20]$.

At the same time, regardless of the value of $L_{\mathrm{xy}}$, an increase in nanometer roughness with an increase in the value of charge $q_{\text {mod }}$ is observed

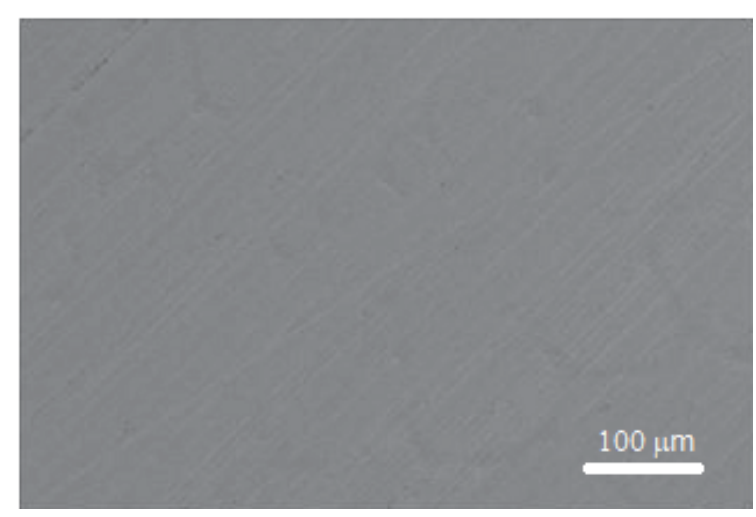

C

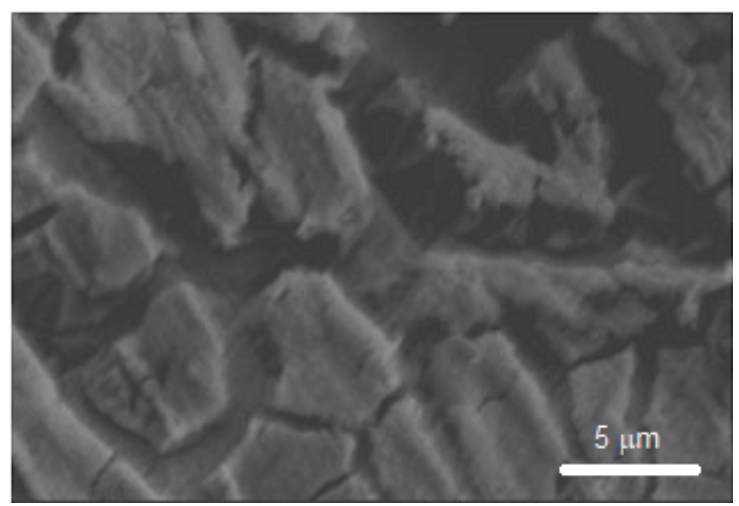

$d$ 


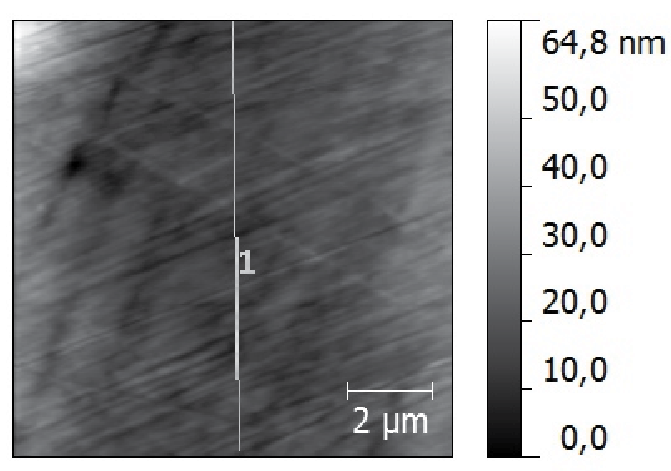

$a$

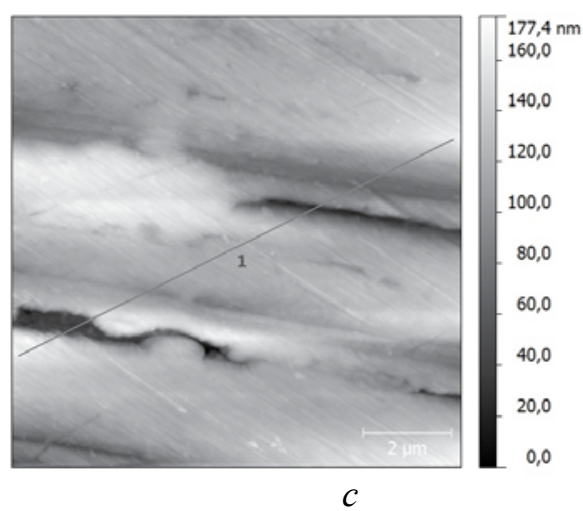

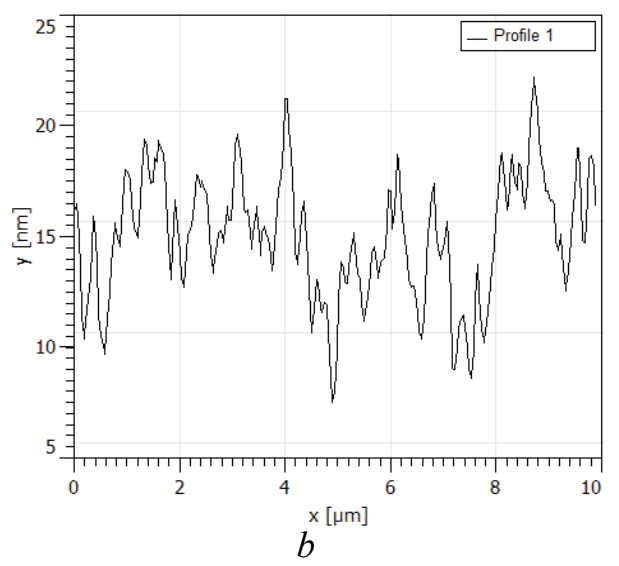

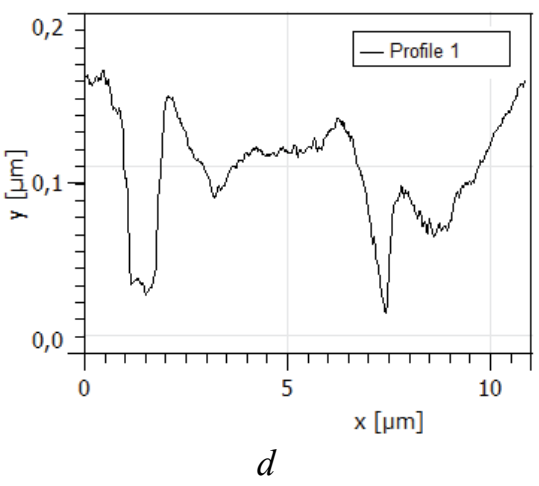

Fig. 2. Topographic AFM images and microscopic profiles of the surfaces of anodically modified Ag4Pd alloy in the initial state $(a, b)$ and after anodic modification $(c, d)$. Modification mode: $E_{\bmod }=888 \mathrm{mV}, q_{\bmod }=141 \mathrm{mC} / \mathrm{cm}^{2}$

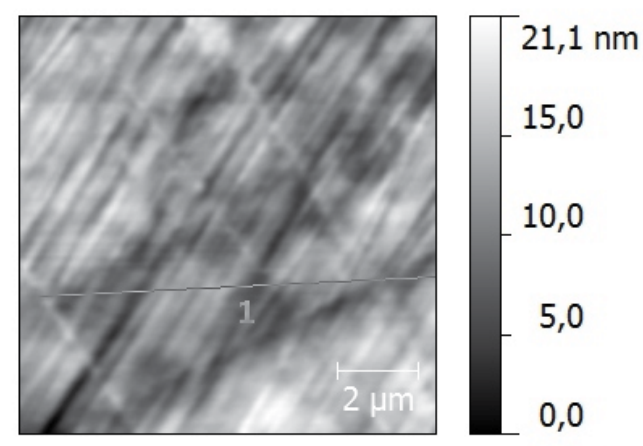

$a$

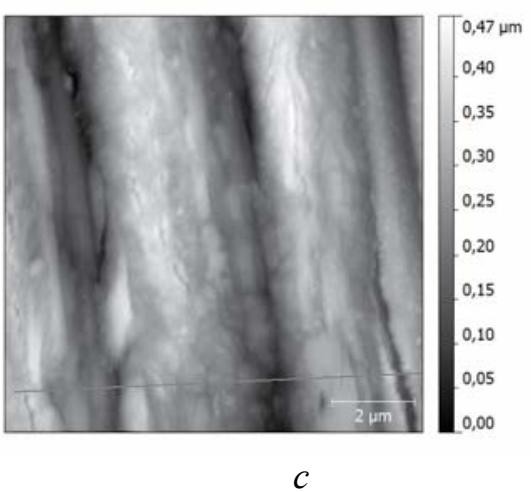

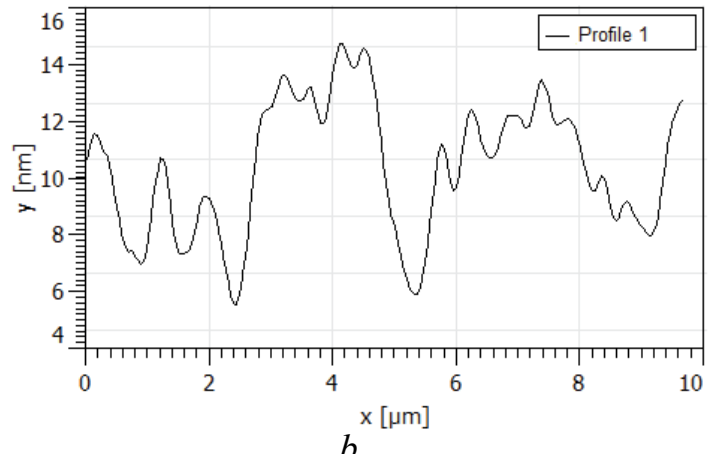

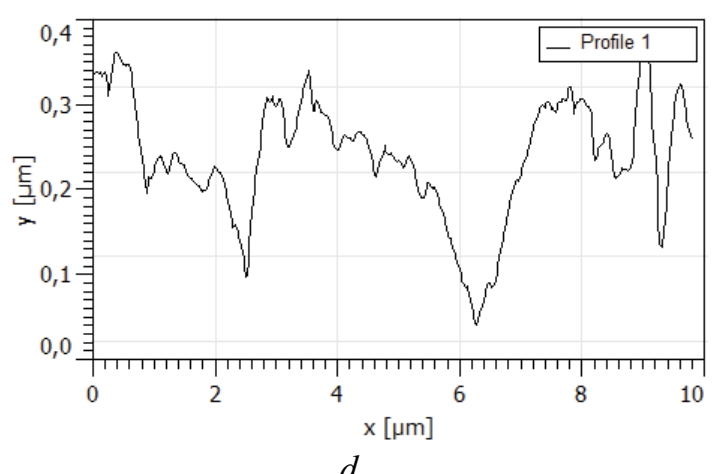

Fig. 3. Topographic AFM images and microscopic profiles of the surfaces of anodically modified Ag8Pd alloy in the initial state $(a, b)$ and after anodic modification $(c, d)$. Modification mode: $E_{\bmod }=903 \mathrm{mV}, q_{\bmod }=243 \mathrm{mC} / \mathrm{cm}^{2}$ 

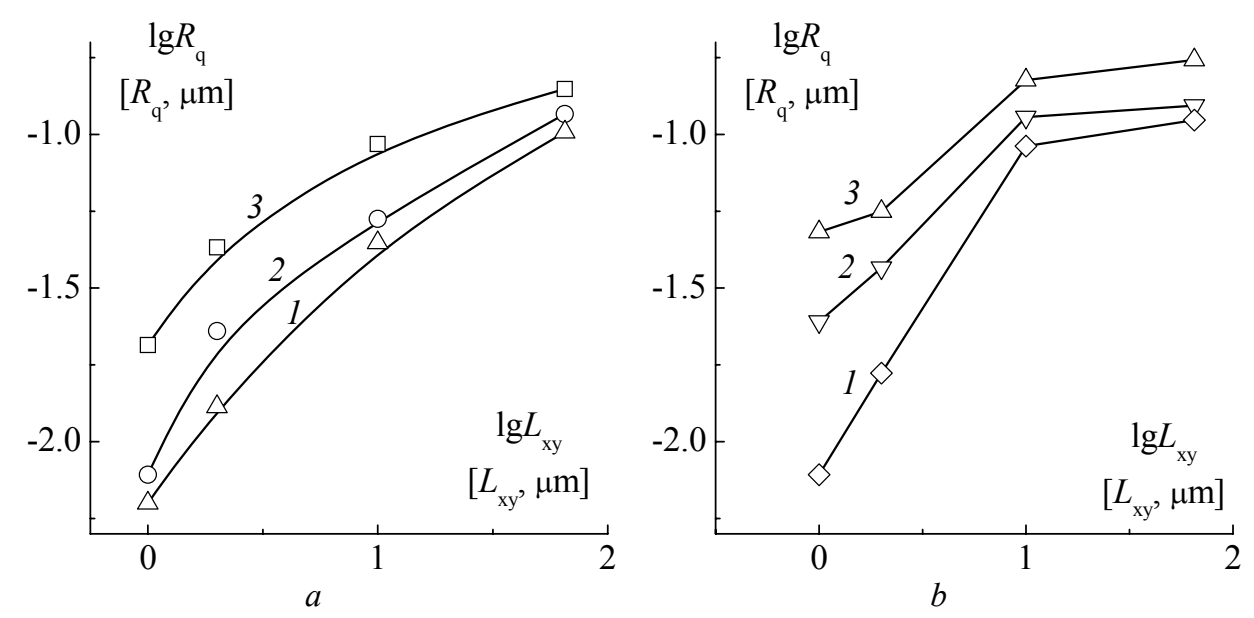

Fig. 4. Root-mean-square roughness vs. scan area size curves for anodically modified alloys Ag4Pd $(a)$ and $\mathrm{Ag} 8 \mathrm{Pd}(b)$. Modification modes: (1) $-E_{\text {mod }}=888 \mathrm{mV}, q_{\text {mod }}=28 \mathrm{mC} / \mathrm{cm}^{2},(2)-E_{\text {mod }}=888 \mathrm{mV}, q_{\text {mod }}=56 \mathrm{mC} / \mathrm{cm}^{2},(3)-E_{\text {mod }}=888 \mathrm{mV}$, $q_{\text {mod }}=113 \mathrm{mC} / \mathrm{cm}^{2},(4)-E_{\text {mod }}=773 \mathrm{mV}, q_{\bmod }=16 \mathrm{mC} / \mathrm{cm}^{2},(5)-E_{\bmod }=823 \mathrm{mV}, q_{\bmod }=58 \mathrm{mC} / \mathrm{cm}^{2},(6)-E_{\bmod }=903 \mathrm{mV}$, $q_{\text {mod }}=486 \mathrm{mC} / \mathrm{cm}^{2}$

for both Ag4Pd and Ag8Pd alloys (Fig. 5). Using the example of Ag8Pd system, it was also found that the parameters $R_{\mathrm{a}}$ and $R_{\mathrm{q}}$ increase with increasing excess of the potential $E_{\text {mod }}$ of the anodic modification over the critical value $E_{\mathrm{cr}}$. The observed effect can be explained by a noticeable increase in the rate of the dealloying process at $E>E_{\mathrm{cr}}, q>q_{\mathrm{cr}}[1,2,4]$ and, as a result, by the formation of deeper extended structural defects in the surface layer of selectively dissolving AgPd alloys.

Thus, varying the values of anode potential $E_{\text {mod }}$ and charge $q_{\text {mod }}$ passed through the system allows to obtain electrode materials with a given degree of surface development, manifested in the appearance of channels and cracks of nano- and micrometer scale, which are absent before the onset of anodic polarization.

Along with the arithmetic mean and rootmean-square roughness, we determined the radial wavelength of the microrelief $L_{a}$, and estimated the dependence of the surface development factor on time $f_{\mathrm{r}}(t)$. We used the simplifying assumption that the microprofile of the surface of Ag-Pd electrodes can be described by a harmonic sinusoidal function. It was taken into account that if the roughness values $R_{\mathrm{a}}$ are significantly less than the average distance between the irregularities $L_{\mathrm{a}}$, then the following expression can be used the dependence of the roughness factor on the time of anodic selective dissolution of the alloy [21]:

$$
f_{r}(t) \approx 1+\frac{2 \pi^{2} \cdot R_{a}^{2}(t)}{L_{a}^{2}} .
$$

The analysis showed that the average height of surface irregularities increases with time of anodic modification according to the square root law (Fig. 6), i.e. $R_{a}(t) \approx$ const $\cdot \sqrt{t}$. This indirectly confirms the data on the diffusion control of the process of selective dissolution of Ag-Pd alloys in an acidic nitrate medium, previously obtained by non-stationary electrochemical methods [16]. Moreover, the average wavelength $L_{\mathrm{a}}$ of a microprofile takes a constant value, and $L_{\mathrm{a}}>>R_{\mathrm{a}}$. Taking into account the totality of the analysis data, the dependence of the surface development degree on time can be described by a linear function as follows:

$$
f_{r}(t) \approx 1+\text { const } \cdot t \text {. }
$$

This function coincides with the formula for the transient roughness factor of selectively dissolving studied Ag-Pd-alloys which we obtained earlier [22] using the voltammetric method. This indicates a correlation between the integral and local characteristics of the surface roughness of the studied electrode systems, which were found independently using non-stationary electrochemical and microscopic methods.

\section{CONCLUSION}

The surface roughening of Ag-Pd alloys during dealloying in nitrate aqueous solution is confirmed by SEM and AFM methods. It was shown that the local roughness of anodically modified alloys increas- 


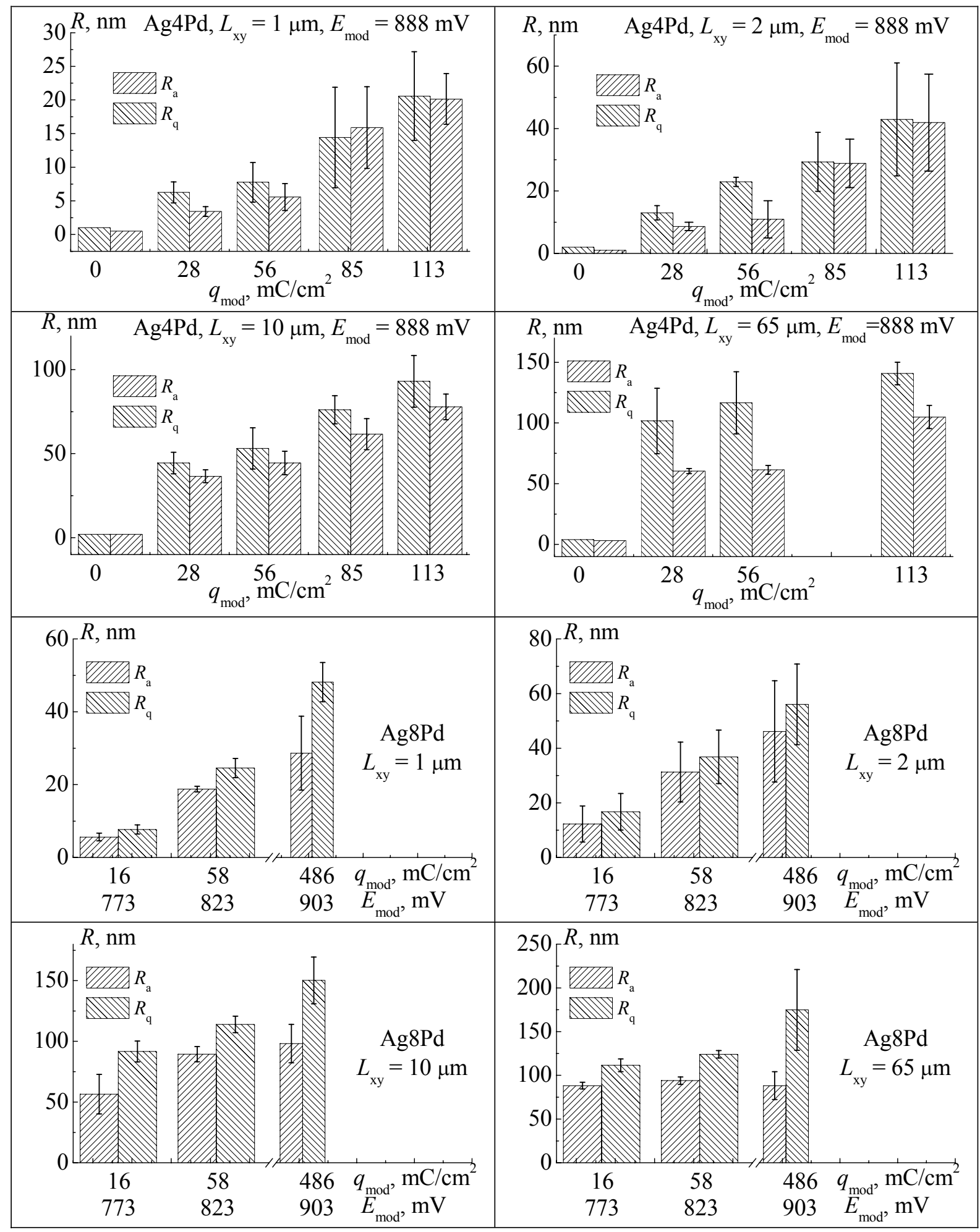

Fig. 5. Average surface roughness of Ag-Pd alloys at different conditions of anodic modification. $L_{\mathrm{xy}}$ is a AFM scanning area size 
es with the overcritical potential and charge of anodic dissolution for both studied Ag4Pd and Ag8Pd alloys. Using the results of the work it is possible to optimize the conditions of the electrochemical dealloying synthesis of new electrode materials with given integral and local characteristics of the surface, such as the real surface area, arithmetic mean and rootmean-square roughness, as well as radial wavelength of the microrelief.

Fig. 6. Criterion dependence of the arithmetic mean surface roughness of $\mathrm{Ag} 4 \mathrm{Pd}$ alloy on time of anodic modification, $E_{\text {mod }}=888 \mathrm{mV}$

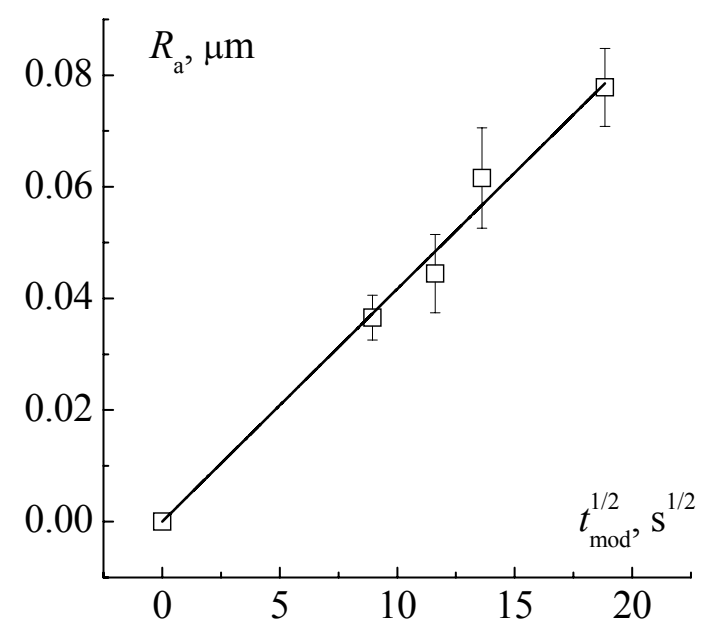

УДК 544.653.22+539.211

\title{
ЛОКАЛЬНЫЕ ПАРАМЕТРЫ ШЕРОХОВАТОСТИ ПОВЕРХНОСТИ АНОДНО-МОДИФИЦИРОВАННЫХ Аg,Рd-СПЛАВОВ
}

\author{
(C) 2018 Е. В. Бедова, М. В. Гречкина, О. А. Козадеров
}

Воронежский государственный университет, Университетская пл., 1, 394018 Воронеж, Россия e-mail: ok@chem.vsu.ru

Поступила в редакцию 28.10.2018

\begin{abstract}
Аннотация. Локальные характеристики шероховатости поверхности поликристаллических твердых растворов системы Ag-Pd (4 и 8 ат.\% Pd) после их потенциостатического электрохимического селективного растворения в кислой нитратной водной среде определены с помощью сканирующей электронной и атомно-силовой микроскопии. Качественный анализ СЭМ- и АСМмикрофотографий подтверждает существенное морфологическое развитие поверхности $\mathrm{Ag}, \mathrm{Pd}$ сплавов из-за образования пор и трещин, вызванного избирательным вытравливанием электроотрицательного компонента (серебра) и перекристаллизацией электроположительного компонента (палладия) в собственную высокоразвитую фазу. Количественным анализом АСМ-данных определены численные значения основных характеристик локальной шероховатости анодномодифицированных сплавов. Отрицательное значение коэффициента поверхностной асимметрии указывает на образование глубоких полостей во время процесса селективного растворения. Средняя микро- и наношероховатость поверхности сплавов Ag4Pd и Ag8Pd не зависит от размера зоны АСМ-сканирования, если он превышает несколько десятков микрометров, а также увеличивается с анодным потенциалом и электрическим зарядом электрохимической модификации. Данный эффект можно объяснить существенным повышением скорости анодного растворения серебра из сплавов в закритической области анодной поляризации, что приводит к образованию более глубоких поверхностных дефектов. Увеличение средней высоты неровностей поверхности со временем модификации подчиняется закону квадратного корня, что косвенно подтверждает нестационарную диффузионную кинетику процесса селективного растворения. Варьирование анодного потенциала и электрического заряда позволяет оптимизировать условия электрохимического синтеза электродных Ag,Pd-материалов с заданными значениями среднеарифметической и среднеквадратичной шероховатости. В предположении, что микропрофиль поверхности Ag,Pd-сплавов описывается гармонической синусоидальной функцией, подтверждена линейная зависимость фактора шероховатости от времени селективного растворения.
\end{abstract}

Ключевые слова: селективное растворение, $\mathrm{Ag}, \mathrm{Pd}-$ сплавы, шероховатость поверхности, СЭМ, ACM.

DOI: https://doi.org/10.17308/kcmf.2018.20/627 


\section{REFERENCES}

1. Bard A. J., Stratmann M., Frankel G. S. Encyclopedia of Electrochemistry. Vol. 4. Corrosion and Oxide Films. Weinheim, Wiley-VCH, 2003, 745 p.

2. Landolt D. Corrosion and Surface Chemistry of Metals. EPFL Press, 2007, 632 p.

3. Kaesche H. Corrosion of Metals. Physicochemical Principles and Current Problems. Berlin, Springer-Verlag, 2003, $601 \mathrm{p}$.

4. Marshakov I. K., Vvedenskii A. V., Kondrashin V. Yu., Bokov G. A. Anodnoe rastvorenie i selektivnaya korroziya splavov [Anodic Dissolution and Selective Corrosion of Alloys]. Voronezh, VSU Publ., 1988, 208 p. (in Russ.)

5. Zhang Z., Wang Y., Qi Z., Somsen C., Wang X., Zhao C. J. Mater. Chem., 2009, vol. 19, p. 6042-6050. DOI: https://doi.org/10.1039/B904052H

6. Kong Q., Lian L., Liu Y., Zhang J., Wang L., Feng W. Microporous and Mesoporous Materials, 2015, vol. 208, no. 5, pp. 152-159. DOI: https://doi.org/10.1039/B904052H 10.1016/j.micromeso.2015.01.017

7. Zhang Z., Wang Y., Qi Z., Zhang W., Qin J., Frenzel J. J. Phys. Chem. C, 2009, vol. 113, no. 29, pp. 12629-12636. DOI: https://doi.org/10.1039/B904052H 10.1021/ jp811445a

8. Yeh W. J., Chava S. J. Vac. Sci. Tech. B: Microelectronics and Nanometer Structures, 2009, vol. 27, no. 2, pp. 923-927. DOI: https://doi.org/10.1039/B904052H 10.1116/1.3032903

9. Erlebacher J., Aziz M. J., Karma A., Dimitrov N., Sieradzki K. Nature, 2001, vol. 410, no. 6827, pp. 450-453. DOI: https://doi.org/10.1039/B $904052 \mathrm{H}$ $10.1038 / 35068529$

10. Detsi E., Schootbrugge M., Punzhin S., Onck P.R., Hosson J. T. M. Scripta Materialia, 2011, vol. 64, pp. 319322. DOI: https://doi.org/10.1039/B904052H 10.1016/j. scriptamat.2010.10.023

11. Hakamada M., Mabuchi M. Materials Transactions, 2009, vol. 50, no. 3, p. 431-435. DOI: https://doi.org/ 10.1039/B904052H 10.2320/matertrans.MBW200825
12. Bard A. J., Faulkner L. R. Electrochemical Methods. Fundamentals and Applications. New York, J. Wiley\&Sons, 2000, 856 p.

13. McNaught A. D., Wilkinson A. Compendium of Chemical Terminology. The Gold Book. New York, Blackwell Science, 1997, 464 p.

14. Trasatti S., Petrii O. A. Pure Appl. Chem., 1991, vol. 63, no. 5, pp. 711-734. DOI: https://doi.org/10.1039/ B904052H 10.1351/pac199163050711

15. Arutyunov P. A., Tolstikhina A.L., Demidov V. N. // Zavodskaya laboratoriya. Diagnostika materialov [Industrial laboratory. Diagnostics of materials], 1999, vol. 65, no. 9, pp. 27-37. (in Russ.)

16. Kozaderov O. A., Dorokhov A. V., Vvedenskii A. V. Protection of Metals and Physical Chemistry of Surfaces, 2012, vol. 48, no. 4, pp. 411-418. DOI: https://doi. org/10.1039/B904052H 10.1134/S2070205112040089

17. Shcheblykina G. E., Bobrinskaya E. V., Vvedenskii A. V. Protection of Metals, 1998, vol. 34, no. 1, pp. 6-9. (in Russ.)

18. Kozaderov O. A. Diss. doct. chem. nauk. Voronezh, 2016. 361 p. (in Russ.)

19. Tong W. M., Williams R. S. Ann. Rev. Phys. Chem., 1994, vol. 45, pp. 401-438. DOI: https://doi.org/10.1039/ B904052H 10.1146/annurev.pc.45.100194.002153

20. Collins G. W., Letts S. A., Fearon E. M., McEachern R. L., Bernat T. P. Phys. Rev. Lett., 1994, vol. 73, no. 5, pp. 708-711. DOI: https://doi.org/10.1039/B904052H 10.1103/PhysRevLett.73.708

21. Kozaderov O. A., Vvedenskii A. V. Massoperenos i fazoobrazovaniye pri anodnom selektivnom rastvorenii gomogennykh splavov [Mass transfer and phase formation during anodic selective dissolution of homogeneous alloys]. Voronezh, Nauchnaya kniga Publ., 2014, 288 p. (in Russ.)

22. Ikonnikova E. V, Grechkina M. V, Kozaderov O. A. Proceedings of Voronezh State University. Series: Chemistry. Biology. Pharmacy, 2014, no. 1, pp. 34-37. Available at: http://www.vestnik.vsu.ru/pdf/chembio/2014/01/201401-06.pdf (in Russ.)

Eugenia $V$. Bedova - postgraduate, Physical Chemistry Department, Voronezh State University, Voronezh, Russia; tel.: +7(473) 2208538, e-mail: iev.vsu@mail.ru

Margarita V. Grechkina - Leading Engineer, Semiconductor Physics and Microelectronics Department, Voronezh State University, Voronezh, Russia; tel.: +7(473) 2208481, e-mail: grechkina_m@mail.ru

Oleg A. Kozaderov - Dr. Sci. (Chem.), Associate Professor, Physical Chemistry Department, Voronezh State University, Voronezh, Russia; tel.: +7(473) 2208538; e-mail: ok@chem.vsu.ru 